\title{
Optegnelser om Robert Walser
}

\author{
ELIAS CANETTI
}

Robert Walsers særegenhed som digter består $i$, at han aldrig udtaler sine motiver. Han er den mest forborgne af alle digtere. Altid går det ham godt, altid er han henrykt over alt. Men hans sværmeri er koldt, da det udelader en del af hans person, og derfor er det også uhyggeligt. Alt bliver til ydre natur for ham, og det egentlige ved den, det inderste, angsten, fornægter han et helt liv.

De stemmer, der hævner sig på ham for alt det hemmeligholdte, udvikler sig først sent.

Hans digtning er et uafladeligt forsøg på at fortie angsten. Han undslipper overalt, før der er for megen angst i ham - hans strejfende liv -, og forvandler sig, til sin redning, ofte til det tjenende og små. Hans dybe og instinktive uvilje mod alt, hvad der er "højt", først og fremmest det, der har magt og gør fordringer gældende, gør ham til en væsentlig digter af vor tid, der er ved at kvæles af magt. Man kvier sig ved ifølge almindelig sprogbrug at kalde ham en "stor" digter, intet er ham så modbydeligt som det "store". Det er kun storhedens glans, han underkaster sig, ikke dens fordringer. Hans lyst er at betragte glansen uden at have del i den. Man kan ikke læse ham uden at skamme sig over alt, hvad der har været vigtigt for en i det ydre liv, og således er han en helgen for sig, ikke ifølge overleverede og tomme forskrifter.

Hans erfaring med "kampen for tilværelsen" fører ham ind i den eneste sfære, hvor denne ikke findes mere, sindssygehospitalet, den moderne tidsalders kloster.

Enhver digter, der er blevet è navn og hævder dette navn, ved meget vel, at han netop derfor ikke er det mere, for han forvalter 
positioner som en anden borger. Men han har kendt mennesker, som var så meget digtere, at netop det ikke kunne lykkes for dem. De ender som udslukte og kvalte og har det valg at leve som tiggere, til plage for alle, eller på sindssygehospitalet. Den anerkendte, der ved, at de var renere end han, har svært ved at holde ud at have dem i sin nærhed i længere tid, men er gerne parat til at ære dem på sindssygehospitalet. De er hans afhuggede sår og vegeterer som sådanne videre. Det er gribende at betragte og kende sårene, blot man ikke føler dem på sig selv mere.

Det pinefulde ved succes: den tages altid fra andre, og kun de intetanende, de indskrænkede, som ikke siger til sig selv, at der blandt de berøvede altid var nogle, som var bedre end de selv, er i stand til at nyde den.

Den anseelse, digterne får af deres martyrer: af Hölderlin, Kleist, Walser. Således udgør de, med alle deres fordringer på frihed, vidde og digterisk fantasi, ikke andet end en sekt.

Jeg er træt af at ride på disse digterfordringers høje hest. Jeg er ikke engang et menneske endnu.

„Jeg kan kun ånde i de nedre regioner." Denne sætning af Robert Walser burde være digternes løsen. Men hofsnogene siger den ikke, og de, der har vundet ry, tør ikke tænke den mere. „Kunne De ikke glemme Deres berømmelse lidt?" sagde han til Hofmannsthal, og ingen har mere kraftfuldt betegnet det pinlige ved dem, der er øverst.

Jeg spørger mig selv, om der blandt dem, der bygger deres bekvemme, snorlige akademiske liv på en digters, der har levet $\mathrm{i}$ elendighed og fortvivlelse, er én, der skammer sig.

På dansk ved Karsten Sand Iversen 